\title{
Vizuální nevědomí: vizuální organizace nevizuálního města ${ }^{1}$
}

\author{
Optical Unconscious: Visual Organization \\ of the Non-Visual City
}

Robert Osman, Pavel Doboš

\begin{abstract}
This article focuses on the organization of space. The practices through which we grasp and conceive space are the paper's concern. Practices emanating from the visual organization of space are usually so commonplace for seeing people so that these practices are only poorly reflected in seeing people's understandings of space. This is why we turn to the experience of visually impaired people. Our understanding of this experience is based on interviews with 16 communication partners from Prague and Brno in 2014 and 2015. We use the poststructuralist approach of philosopher Gilles Deleuze, psychoanalyst Félix Guattari and geographer Marcus Doel to interpret the interviews and we show that visual impairment is not about non-seeing, but about becoming seeing differently - via the non-visual percept. Yet, such practices of seeing space differently are still shaped by the modern collective optical unconscious. Doel asserts that this unconscious has been structured by the medium of film, among others, and the film technique of montage. This has made the optical unconscious obscene. Montage unbound time and space from their firm coordinates and enabled seeing beyond screened frames. This strengthened the incorporeality of spatial experience. Visually impaired people's practices of seeing and dealing with the optical unconscious accentuate the corporeality of sight again, however. Their practices fuse the seeing via non-visual percept and the optical unconscious into new configurations, demonstrating that no way of seeing can be incorporeal.
\end{abstract}

KEY WORDS disability geography, visually impaired people, poststructuralism, optical unconscious, space, city

\section{Úvod}

Každý prostor je nějak organizován. Řekne-li se, že prostor je nějak organizován, mnoho lidí si obvykle představí, že prostor nabývá nějakých struktur, které ho rozčleňují, jeho jednotlivým částem dávají nějaké charakteristiky, určují, co má být tady a co má být jinde, nebo definují nějaké typické a očekávané užívání prostoru. Takto se obvykle chápe konvenční koncepce organizace prostoru: prostor jako prvek, který je dopředu esenciálně daný ve své

Sociální studia / Social Studies 1/2019. S. 33-55. ISSN 1214-813X.

1 Př́spěvek vznikl s finanční podporou Grantové agentury České republiky GAČR jako součást projektu č. 17-16097S „Prostorová nespravedlnost automobilitních technologii““. 
úplnosti, a organizace prostoru jako činnost, která s tímto daným prostorem nějak zachází, nějak ho usměrňuje, nějak ho tvaruje, dává mu nějakou strukturu a nějaký řád, aby poté mohl prostor vzniknout ve své modifikované podobě - jako organizovaný prostor. Tato koncepce organizace prostoru je obvyklá pro velkou část sociální vědy, která s prostorem nějakým způsobem pracuje - sociální vědu, která zkoumá urbánní prostor, nevyjímaje. Tato koncepce se zdá často tak samozréejmá, že zneviditelňuje jinou, hlubší otázku organizace prostoru otázku, jak a čím je vůbec organizován tento prvně daný prostor, který vždy figuruje jako dopředu existující, který vždy figuruje v prvé řadě jako ten prostor, s kterým pracujeme, jako prostor, na který vždy až a posteriori „navlékáme“ nějakou organizaci, která ho strukturuje, rozčleňuje a dává mu řád. Jinými slovy, zneviditelněna bývá otázka, co vytváří a organizuje tuto domněle apriorní esenci prostoru, s kterým pracuje sociální věda.

Abychom mohli zodpovědět tuto otázku, obracíme se ke dvěma specifickým oblastem sociální vědy jako perspektivám, díky jejichž kombinaci chceme zviditelnit hlubší organizaci esence ${ }^{2}$ prostoru: ke geografii znevýhodnění a poststrukturalistické geografii. Ta první (geografie znevýhodnění) nám umožňuje reflektovat, že tato organizace prostoru je praktikována ze specifické pozice lidí, kteří jsou tělesně „normálni“. Této reflexe dosahujeme tím, že se obracíme ke zkušenosti lidí, kteří za tělesně „normální“ obvykle označováni nejsou - v našem př́ípadě ke zkušenosti lidí, kteří nedisponují tělesným smyslem zraku. V průběhu let 2014 a 2015 byly provedeny polostrukturované rozhovory s 16 komunikačními partnery a partnerkami (dále jen KP) žijícími především v Praze a Brně, kteří mají různým způsobem omezenou schopnost vidět zrakem. KP byli vybíráni pomocí metody sněhové koule a jejich výběr byl prováděn se zvláštním zřetelem na jejich heterogenitu (od narození, v průběhu života, úplná ztráta zraku, zbytky zraku, kombinované znevýhodnění, s vodicím psem, s asistenčním psem atp.). Rozhovory byly provedeny na obecnější téma, vedeny velmi doširoka otevřenou otázkou: Jakým zpưsobem osoby se zrakovým znevýhodněním proživaji prostor? Na základě těchto dat vznikl předchozí př́spěvek poukazující na reflexi vizuality prostoru jako prostorový normativ (Osman a Pospíšilová 2016) ${ }^{3}$. Př́íspěvek se tak vrací k těmto datům a znovu jich využívá. Provádí s nimi novou analýzu, vedenou výrazně užší výzkumnou otázkou. Ta byla formulována do podoby: Jak může zkušenost lidí, kteři podle svých vlastních slov nevidí, napomoci k porozumèni organizaci městského prostoru?

Takto formulovaná výzkumná otázka odkazuje $\mathrm{k}$ druhé perspektivě, pomocí níž chceme zviditelnit hlubší organizaci esence prostoru - k poststrukturalistické geografii. Poststrukturalistická geografie nám totiž umožňuje zpochybnit, že vůbec cokoli na tomto světě (včetně prostoru) obsahuje jakoukoli esenci, nutí nás pátrat po tom, co za praktiky vlastně tyto domnělé esence utváríi (a zároveň jaké praktiky jsou jimi utvářeny), co stojí za jejich udržováním a kde naopak hledat cesty, jež by vedly $\mathrm{k}$ jejich zpochybnění a přetváření. Poststrukturalistická geografie také odmítá konvenční rozdělování materiálního a tělesného

$2 \quad \mathrm{~V}$ poststrukturalistické perspektivě deleuze-guattariánské provenience, což je perspektiva tohoto článku, esence sice existují, avšak nikoli jako transcendentní, nýbrž imanentně ve formě utuhnutí specifických praktik ve strata (Deleuze a Guattari 2010: 51-88).

3 Rádi bychom tak na tomto místě poděkovali Lucii Pospíšilové za ochotu, díky které jsme mohli těchto dat využít i pro předkládaný článek. 
na jedné straně a diskurzivního a vypověditelného na straně druhé - tyto dvě sféry chápe jako dvě strany jedné mince, které nejsou oddělitelné a neustále se koprodukují. ${ }^{4}$ Díky tomu se poststrukturalistická geografie blízce střetává s nejnovější etapou ve vývoji geografie znevýhodnění, již lze nazvat etapou diskurzivně-materiální.

\section{Prostorové znevýhodnění jako perspektiva}

Akademický zájem o „nenormální“ těla má za sebou už poměrně dlouhou cestu v podobě studií znevýhodnění (disability studies), nicméně zájem o „nenormální“ těla v prostoru je o poznání kratší. Snahy o zpřístupnění prostoru, veřejného prostoru, a především veřejných služeb a institucí je spojen s rozvojem normativních konceptů univerzálního designu prostoru (universal design), inkluzivního designu prostoru (inclusive design) či prostoru pro všechny (design for all), jejichž počátky lze vysledovat až do šedesátých let minulého století. Systematicky jsou však rozvíjeny až od let osmdesátých. Tato materialistická perspektiva však zůstávala omezena pouze na prostorovou přístupnost lidí k nejrůznějším zdrojům, službám a technologiím. Otázky „normality“ prostorových konceptů a teorií, respektive otázky, jakými těly a pro jaká těla jsou prostorové koncepty a teorie budovány, se však objevily ruku v ruce s geopolitickou argumentací až v rámci geografie znevýhodnění (disability geography $)^{5}$. Počátky geografie znevýhodnění můžeme klást do první poloviny devadesátých let minulého století a její vývoj lze rozdělit do tří odlišných etap, přičemž tyto fáze můžeme zjednodušeně označit jako i) behaviorální, ii) sociální a iii) diskurzivně-materiální. První fáze a obecně počátky geografie znevýhodnění jsou spojeny s tzv. behaviorální geografií, která představuje reakci na ryze kvantitativní způsoby výzkumu „normativního“ prostorového chování předpokládající racionálně uvažující, plně informovaný a osobní užitek maximalizující subjekty (homo economicus). Behaviorální geografie rozvíjela kritiku takto chápaného subjektu a zpochybňovala plnou informovanost lidí, zdůrazňovala diferencovanou schopnost pracovat s těmito informacemi, diferencovanou schopnost rozhodovat se, a především kladla důraz na diferencovanou schopnost vnímání prostorových informací (Wolpert 1964; Ley 2000: 43; Phillips 2005: 27).

Určitým zlomem, od kterého lze pozorovat počátek zájmu geografie o studium znevýhodnění, je rok 1984, ve kterém jeden z předních představitelů behaviorální geografie, americký geograf Reginald George Golledge, oslepl (Kitchin 2008: 137). Tato událost výrazně

4 Výraz koprodukce v celém článku sleduje dva záměry: Zaprvé vyjádřit, že dva prvky (tělesné a diskurzivní, subjekty a struktury, organizace a konzistence) se navzájem spolu-utvářejí a stávají: jedno se stává druhým, druhé se stává prvním. Zadruhé ale také vyjádřit, že tyto dva prvky, které jsou sice kvalitativně odlišitelné, nejsou vlastně díky neoddělitelnosti své ontogeneze dva prvky, ale prvek jeden: ono se stává (toto ono však neni dialektickou syntézou). Proto zde předpona „ko-“ figuruje ve svých dvou významech: „spolu“ (jedno s druhým) i „dohromady“ (jedno). Jde o deleuze-guattariánské sjednocení monismu a pluralismu (Deleuze a Guattari 2010: 30).

5 Geografie znevýhodnění je poměrně nová subdisciplína stojící na pomezí sociální geografie (social geography) a studií znevýhodnění (disability studies), jejíž stručný vývoj nám poslouží k objasnění naší motivace $\mathrm{k}$ sepsání tohoto textu a přijetí prostorového znevýhodnění jako analytické perspektivy. 
ovlivnila jeho další akademickou kariéru, ve které se po boku psychologa Jakca Loomise a psycholožky Roberty Klatzky začal věnovat výzkumu orientace a navigace nevidomých lidí v prostoru. Tyto práce se nicméně nezabývaly porozuměním prostorové zkušenosti nevidomých lidí, měly spíše povahu aplikovaného výzkumu, jehož primárním cílem byl návrh GPS navigace pro zrakově postižené osoby (UCSB Personal Guidance System), bez výraznější kritické reflexe nástrojů $\mathrm{k}$ tomuto účelu používaných. Za tuto perspektivu byly následně jeho práce také kritizovány. První vlnu kritiky odstartoval Golledgův článek „Geography and the Disabled: A Survey with Special Reference to Vision Impaired and Blind Populations" $\mathrm{z}$ roku 1993, který vyvolal vlnu reakcí. Golledge v něm navazuje na teorii nedostatku (deficiency theory) a teorii neefektivity (inefficiency theory) (Andrews 1983; Golledge 1993: 71). Osoby se zrakovým znevýhodněním tak oproti osobám bez zrakového znevýhodnění podle Golledge žijí v odlišném, transformovaném prostř̌edí (transformed space), jež je nekompletní, ochuzené, a tudíž i méně kvalitní (Golledge 1993: 64). Jejich pohybový vzorec je pak díky tomu taktéž omezený (restricted) a méně komplexní (less complex) než u osob bez zrakového postižení (Golledge 1993: 69). Jako určité řešení této situace pak navrhuje vytváření speciálních haptických map pro osoby se zrakovým postižením (Golledge 1993: 76).

Behaviorální fázi vývoje geografie znevýhodnění tak lze označit za do jisté míry asociální $\mathrm{v}$ tom smyslu, že znevýhodnění (disability) chápala pouze $\mathrm{v}$ jeho individuálním významu (impairment) jako fyzické (tělesné) omezení, defekt či nefunkčnost těla (chybějící část těla, nefunkční či omezeně funkční část těla atp.) a za jediný skutečný (objektivní) prostor obdobně pokládala pouze prostor $\mathrm{v}$ jeho fyzické (materiální) podobě, tedy jakýsi asociální soubor materiálních ulic, zdí, domů, schodů, sloupů atp., mezi kterými se tato (fyzická) těla pohybují.

Druhá fáze vývoje geografie znevýhodnění, pracovně nazvaná jako „sociální“, tak představuje reakci na tuto kritiku a je úzce spojená s etablováním sociálního modelu postižení v rámci studií znevýhodnění. Geografové se přitom v kontextu sociálního modelu postižení odkazují především na Paula Abberleyho (1987) či Michaela Olivera (1990, 1991, 1993, 1996). Sociální model postižení zcela proměnil dosavadní př́stup ke studiu znevýhodnění. Po vzoru feministického odlišení biologického pohlaví a sociálně konstruovaného genderu došlo i v geografii znevýhodnění k odlišení biologického postižení (impairment) a sociálně konstruovaného znevýhodnění (disability) (Butler a Bowly 1997: 415), přičemž zatímco individualizované postižení představovalo konkrétní biologické možnosti těla, společenské znevýhodnění vyjadřovalo sociálně produkovanou nerovnost podmínek (Gleeson 1996; Imrie 1996). O postižení se tak přestalo nadále uvažovat jako o individuálním omezení možností těla, za které je odpovědný jedinec, ale jako o kolektivním vyloučení určitých členů z určitých činností, za které je odpovědná celá společnost. Gleeson v tomto kontextu hovoří o socializaci, respektive o denaturalizaci tělesného postižení (Gleeson 1999, 2001: 262), což neznamená nic jiného, než že v rámci behaviorální fáze vývoje geografie znevýhodnění nebyla výzkumná pozornost věnována sociálnímu rozměru postižení, zatímco sociální fáze se v reakci na předchozí fázi zaměřuje naopak výhradně na ně (Park, Radford a Vickers 1998).

Tento významový posun spojený s prosazením sociálního modelu se v geografii znevýhodnění nicméně neomezil pouze na pojetí postižení, ale měl vliv i na pojetí samotného prostoru. I prostor přestal být významově prázdným, asociálním kontejnerem (Gleeson 1996: 390), ale začal být chápán relačně jako soubor sociálně utvářených vztahů (Doel 1999; Masey 
2005; Murdoch 2006). Gleeson opět analogicky hovoří o socializaci prostoru (socialization of space) (Gleeson 2001: 252). Prostor tak po vzoru sociálního modelu postižení není pouze ten fyzický (jako pohlaví či impairment), ale i sociální, tedy sociálně produkovaný ${ }^{6}$ (jako gender či disability) (Wolch a Dear 1989). Pokud je prostor navrhován tak, že vylučuje určité členy společnosti z př́stupu do něj (apartheid design) (Imrie 1996), tento prostor pak dává aktivně najevo, že do něj tito členové společnosti nepatří, tedy že jsou „out of place“ (Chouinard a Grant 1995: 139-141; Kitchin 1998: 351; Chouinard 1999: 150; Hansen a Philo 2007: 496), což lze poměrně snadno číst jako sdělení většinové společnosti, jako: „ty sem nepatříš, ty jsi jiný“ (Kitchin 1998: 345). Zatímco pokud je prostor naopak navrhován jak pro osoby s, tak i bez tělesného postižení, tato diferenciace se neuplatňuje a lze tak v prostoru číst sdělení „všichni jsme si zde rovni“ (Dear, Gaber, Takahashi a Wliton 1997: 473-474).

Třetí fázi vývoje geografie znevýhodnění pak lze nazvat jako „diskurzivně-materiální“. Opět se jedná o reakci na předchozí fázi, kdy na základě kritiky př́lišného důrazu na sociální rozměry jak znevýhodnění, tak i prostoru vzniká odpověd’ v podobě hledání způsobů, jak propojit sociální (diskurzivní) a fyzickou (tělesnou/materiální) stránku jak postižení, tak i prostoru. Přestože se socializace, respektive denaturalizace tělesného postižení (Gleeson 1999, 2001: 262) netýká geografie znevýhodnění $\mathrm{v}$ takové míre jako jiných, méně prostorových studií znevýhodnění, i zde dochází k podobnému efektu, kdy po př́lišném důrazu na materialitu postižení (v rámci behaviorální fáze) přichází př́lišný důraz na diskurzivitu znevýhodnění (v rámci sociální fáze) (Goodley, Hughes a Davis 2012: 311), který vyústí v hledání určitého diskurzivně-materiálního kompromisu ve třetí fázi. Geografové se v tomto kontextu nejčastěji odvolávají na Toma Shakespeara (Shakespeare 1993, 1995, 2006, 2014), který sice přiznává sociálnímu modelu určitou politickou hodnotu umožňující mobilizaci aktivismu tělesně, smyslově či mentálně znevýhodněných lidí, nicméně kritizuje jej především za jeho uzavřenost, inercii a neschopnost se dále vyvíjet $\mathrm{v}$ rámci nových diskusí $\mathrm{k}$ alternativním modelům znevýhodnění (Shakespeare 2006: 33-34). Sociální model podle něj ustrnul v nadále (politicky i ontologicky) nekonstruktivním oddělení sociálně (re)produkovaného znevýhodnění (disability) a biologicky omezených možností těla či mysli (impairment), přičemž se věnuje primárně tomu prvnímu a zdravotní postižení jako biologické omezení ponechává stranou, čímž ze zřetele systematicky odstraňuje tělesnou zkušenost lidí žijících s biologickým omezením možností těla či mysli (Shakespeare 2014). V reakci na tuto kritiku se i přes hluboce zakořeněný strach plynoucí z potenciálního návratu $\mathrm{k}$ medicínskému modelu postižení (Hall 2000: 27) začínají hledat způsoby, jak propojit oba rozměry znevýhodnění, tedy jak zohlednit jak jeho sociální (diskurzivní), tak i biologickou (materiální) rovinu (srovnej s Porkertová 2017; Osman 2019). V geografii znevýhodnění je tato kritická reakce spojena především s geografy inspirovanými v poststrukturalistických teoriích (Hall a Wilton 2017: 728). Motivací k sepsání tohoto př́spěvku tak je snaha o navázání na tuto debatu v rámci geografie znevýhodnění a její využití pro promýšlení způsobů, jakými se díváme na prostor našich měst, respektive pro korporealizaci (otělesnění) či denaturalizaci (odpř́rodnění) používaných perspektiv nazírání na

6 Prostor tak není nadále pouze budovami, ulicemi, parky či jinou materiální infrastrukturou, prostor je nově i to, že v knihovnách mluvíme tiše a v kostele pocit'ujeme úctu. Prostor je významuplný, respektive prostor je i těmito významy, které je možné číst podobně jako text (Cresswell 1996: 16). 
městský prostor. Jinými slovy nám nejde o tělesné znevýhodnění jako o předmět zájmu, ale o tělesné znevýhodnění jako o perspektivu, která nám umožňuje zahlédnout prítomnost normálních těl ve způsobech přistupování $\mathrm{k}$ (městskému) prostoru.

\section{Akłualizace nevidomého subjekłu jako „stávání se jiným"}

Předkládaným textem navazujeme na popsaný vývoj geografie znevýhodnění, přičemž chceme konfrontovat přetrvávající nereflexivitu „přítomnosti“ normálních (vidoucích) těl v produkci vědění o (městském) prostoru. Po behaviorální fázi, ve které nebyla dostatečně reflektována vizualita používaných metod (mentální mapy), po sociální fázi, ve které nebyla reflektována vizualita konceptů (výška, délka, úhel, vzdálenost, geometrie, měřítko), bychom rádi tuto debatu posunuli o krok dál a poukázali na přetrvávající nedostatečnou reflexivitu vizuality na epistemologické úrovni, v rámci níž je produkce vědění o (městském) prostoru utvářena. Jinými slovy poukázat na to, že sám proces produkce vědění obsahuje předpoklad o specifickém způsobu vidění, a to vidění pouze zrakem. Chceme tak tímto článkem přispět k pokračování jakési „devizualizace“ výzkumu prostorové zkušenosti lidí nevidomých a zároveň poukázat na možnosti, které nám studium takto „devizualizované“ prostorové zkušenosti může nabídnout při výzkumu (městského) prostoru. $\mathrm{K}$ tomuto účelu v tomto príspěvku využíváme poststrukturalistický príístup. $V$ této sekci podrobně rozebereme, proč poststrukturalistické uvažování opouští dualitu subjekt versus struktura a proč ji nahrazuje konceptem praktik. Současně zde představíme jinou konceptuální dvojici aktuálního a virtuálního.

Proč tak činíme? V př́stupech, které nejsou poststrukturalistické, jsou subjekt a struktura běžně chápány ve smyslu stabilního „bytî“ - jako fenomény, které jsou, a není je tedy nutné komplikovat kategorií virtuálního. $\mathrm{Z}$ toho důvodu bývají subjekt i struktura $\mathrm{v}$ těchto př́istupech spojovány s charakteristikami statičnosti, uzavřenosti a ohraničenosti. $Z$ důvodu využití poststrukturalistického př́stupu opouštíme chápání subjektu a struktury jako stabilního „bytí“ a nahrazujeme je jejich postupným „stáváním se“. Pro podrobnější popis tohoto „stávání se“ subjektu a struktury využíváme právě konceptů virtuálního a aktuálního. Tato nová konceptuální dvojice aktuálního a virtuálního nám posléze umožní uchopit „stávání se“ nevidomého vidomým, tedy i vidění bez zraku.

Základní charakteristikou poststrukturalismu je, že vychází z anti-esencialismu? Politicky řečeno je poststrukturalismus $\mathrm{v}$ podstatě resistencí vůči esencialismu (Newman 2005). Východiskem poststrukturalismu proto nejsou ani stabilní subjekty či identity, jež jsou zkoumány, ani v pozadí existující sociální struktury, které jsou výzkumem odhalovány. Poststrukturalismus nenahlíží na jevy skrze nějaký transcendentně organizovaný prvek, který mají. Ani subjekty, ani struktury nemají žádnou vlastní podstatu, která by byla nezávislá na jejich imanentním utváření se. Poststrukturalismus dichotomii subjekt-struktura nahrazuje konceptem praktik. Jak subjekty, tak i struktury jsou produkovány praktikami. Praktiky jsou činnosti a dění, na nichž je založeno neustálé přetváření se sociálního i materiálního světa. Jde o rozmanité mnohočetné a do značné části nahodilé události a jejich účinky, které nelze

$7 \quad$ Z deleuze-guattariánské perspektivy anti-esencialismus neznamená neexistenci esencí, ale pojetí esencí jako něčeho utuhnutého $\mathrm{z}$ neomezeného průběhu života. 
redukovat ani na strukturu utvářející jednání subjektu, ani na strukturující schopnosti struktury. Praktiky se relativně volně dějí, zatímco subjekty a struktury jsou pouze sedimentacemi tohoto dění a jakékoli další dění je může přetvořit (May 1994: 78).

Anti-esencialistickou kritiku přitom v poststrukturalistické geografii rozvíjí především Marcus Doel $(1996,1999,2000)$ s širokými odkazy na filozofii Gillese Deleuzeho a Félixe Guattariho. Pokud subjekty a struktury pojmeme v tomto anti-esencialistickém významu jako sedimentace praktik, pak nikdy nemohou být aktuální, ale pouze virtuálni. ${ }^{8}$ To ovšem neznamená, že by nebyly reálné, ale znamená to, že se nikdy neaktualizují (ve smyslu nezprítomní) jako jeden stabilní subjekt, anebo jedna stabilní struktura. Subjekt i struktura jsou tedy vždy pouze virtuální. To znamená, že jsou určitým potenciálem, který vychází z právě aktualizovaných praktik a který je směrodatný pro další praktiky, které se teprve budou aktualizovat. Subjekt je tak spíše donekonečna probíhající virtuální potenciál „subjektifikace“ (stávání se subjektem) a struktura donekonečna probíhající virtuální potenciál „Zestrukturnění“ (stávání se strukturou) než aktuální statický subjekt či struktura. Tyto dva potenciály pak v určitý moment společně způsobí, že se v našem světě aktualizují nějaké praktiky - jejichž praktikování následně ovlivní další změnu potenciálu ,subjektifikace“ a „zestrukturnění“. Subjekty a struktury tedy vždy existují jen jako určitý před-moment ${ }^{9}$, z kterého se aktualizuje moment nějakého praktikování, proto jsou vždy jen virtuální, tedy mimo aktuální čas a prostor.

Tab 1: Významová diference konceptuální dvojice aktuální-virtuální

\begin{tabular}{|l|l|l|}
\hline & aktuální & virtuální \\
\hline domény & praktiky & subjekt, struktura \\
\hline koncepty & praktiky & nevidomý subjekt, kolektivní nevědomí \\
\hline termíny & $\begin{array}{l}\text { aktualizace, aktualizování, } \\
\text { dělání, stvoření, zpř́tomnění, } \\
\text { uvedení do přitomnosti }\end{array}$ & $\begin{array}{l}\text { stávání se subjektem/subjektifikace } \\
\text { stávání se strukturou/zestrukturnění } \\
\text { virtualizace, virtualizování, čisté } \\
\text { mimočasové dění }\end{array}$ \\
\hline funkce & praktikování & $\begin{array}{l}\text { potenciál, podmínky, možnosti } \\
\text { pro praktikování }\end{array}$ \\
\hline
\end{tabular}

Aktualizace (utvoření aktuálního) přitom představuje jev, kdy se skrze praktiky zpř́ítomní něco z virtuálního potenciálu právě dané aktuální situace a vznikne tedy nová diskurzivní a materiální výslednost. Rozdíl mezi virtuálním a aktuálním je v tom, že „virtuální je samotné stávání se události: je to, co se děje. Neexistuje žádný efekt reality bez virtuality, žádné bytí bez stávání se. [...] Oproti tomu, aktualizace je stvořeni““ (Doel a Clarke 1999: 278-280) něčeho nového zpř́tomnělého, něčeho nového v časové prrítomnosti. Jde tedy o to,

$8 \quad$ Aktuální a virtuální je jedna z nejdůležitějších konceptuálních dvojic ve filozofii Gillese Deleuzeho a Félixe Guattariho.

9 Před-moment nikoli ve smyslu časové posloupnosti, tedy že by virtuální časově předcházelo aktuálnímu, ale ve smyslu imanentním, tedy že virtuální stojí mimo chronologický čas jako podmínka aktuálního. 
že virtuální je čisté mimočasové a nemateriální dění, čisté podmínky aktualizace, které jsou vždy imanentní samotné aktualizaci, ale přitom vystupují jako její předpoklady. Aktuální je oproti tomu to zpřítomnělé (časově přítomné), to, co vzniká při každé aktualizaci něčeho z čistého dění/virtuálního potenciálu. Přitom se nejedná ani o virtuální subjekt, ani o virtuální strukturu, které něco aktualizují, ale jedná se vždy o neutrální jev, kdy se něco aktualizuje mezi nimi (Deleuze 2014: 177-180). Jinými slovy, aktuálně svět probíhá jen jako praktiky. Ale tyto praktiky musejí vyvěrat z něčeho, co existuje v tomto světě (co je reálné), ale zároveň to není nic stabilního a zpřítomnělého (není to aktuální), nebot' to nejsou praktiky (protože jen ty mohou být aktuální). Proto se praktiky aktualizují vždy z propojení virtuálního potenciálu jak „,subjektifikace“, tak ,zestrukturnění““.

$\mathrm{K}$ čemu je to dobré? K tomu, že pokud v souladu s poststrukturalismem a jeho principem anti-esencialismu akceptujeme, že ve světě neexistuje stabilní transcendentní „,bytí“ (nebot' to by vedlo k esencializaci), ale pouze imanentní „stávání se“ (Doel 1999; Deleuze 2016a; Deleuze a Guattari 2010), potřebujeme identifikovat některé prvky, byt’ neaktuální, které nám umožní „stávání se“ nějakým způsobem uchopit. Tímto neaktuálním prvkem je právě virtuální potenciál „subjektifikace“ a ,zestrukturnění“. Pro poststrukturalismus je tedy klíčová odlišnost mezi „bytím“ a „stáváním se“. Abychom nesklouzli zpět do esencialistického „bytí“, je třeba subjekty a struktury chápat pouze jako virtuální, a tedy jako čisté dění, zatímco to, co je aktuální, pouze jako neustále aktualizované praktiky, tedy jako ryzí stvoření.

To znamená, že sice pracujeme proti snahám o esencializaci, ale zároveň se nevzdáváme možnosti, že něco jako subjekt a něco jako struktura mají stále vliv na sociální život, respektive na jeho praktikování. Nicméně když stále pracujeme na rovině vyhranění se proti esencializaci, znamená to, že nikdy nemůžeme jednoznačně říci, co jsou omezení aktualizovaných praktik, co se v praktikách může stát, co mohou lidé praktikami dokázat, kam je mohou praktiky zavést. Musíme je nechat otevřené. Subjekty a struktury jsou prostě stále jen neustále „se stávajícím“ virtuálním potenciálem - nemají tedy jakoukoli možnost probíhající sociální život determinovat, ba ani nějak zcela předvídatelně tvarovat. Zapojují se pouze do jeho koprodukce, do toho, že se něco z praktik v sociálním životě aktualizuje. Avšak virtuální subjekt a virtuální struktura jsou přece jen ve svém „stávání se“ odlišné. Proto je na místě diskutovat o nich na chvíli samostatně.

Nejprve se zaměříme na „stávání se“ subjektem, tedy na „subjektifikaci“: pokud jakýkoli člověk není na prvním místě aktuální subjekt, ale je pouze aktuálně praktikován, je třeba se ptát, kam člověka zařadit, jakým způsobem člověka uvažovat. Třebaže člověk nikdy není aktualizovaným subjektem v př́ítomnosti, neustále se nějakým subjektem „stává“, neustále je subjektem, který má teprve přijít, tedy subjektem, který se tzv. virtualizuje. Představa aktuálního subjektu jako stabilního „bytí“ je omezující, ohraničující, diskriminující, a proto v poststrukturalismu zásadně existuje jen a pouze na odlišné ontologické rovině (s kterou zde nepracujeme a vůči které se vymezujeme). Oproti tomu představa virtuálního subjektu jako neustálého „stávání se“ je otevřená čemukoli. Doel (1995: 212) vysvětluje: „Lidský subjekt je vždy plné tělo, které má teprve přijít: vyvstává, aniž by jako takový existoval. Bytí je Stávání se.“ „Proto je subjekt vždy tvořením-v-postupu, sociálním aparátem procházejícím kontinuální variací stávání-se-jiným. [...] Zkrátka, subjekt vyvstává skrze kontinuální variaci udržování předchozího sebe a stávání-se-jiným“ (Doel 1995: 216). „Libovolné [lidské bytosti] pak již 
nadále nevymezujete [jejich] formou, [jejich] orgány a funkcemi, a rovněž je nepojímáte jako [aktuální] subjekt[y]. Nýbrž je definujete pomocí afektů“, které prodělávají při svém „stávání se" subjekty (Deleuze 2016b: 113).

Klíčový prvek „stávání se“ proto není nějaká identita subjektu, ani nějaká hybridizace více identit subjektu, nýbrž doplňování virtuálního subjektu o další a další prvky, které vycházejí z právě aktualizovaných praktik (Doel 1999: 42). Jde o doplňování do nikdy neukončené plnosti. Subjekt jako entita tedy v tomto pojetí neexistuje ve smyslu „bytí“. A pokud tedy odstraníme subjekt jako „bytí“, jediné, co nám zbyde, je tělo - protože tělo nikdy nelze pojmout ve smyslu stabilního „bytí“, tělo vždy existuje pouze ve smyslu „stávání se“ tělem. V tomto smyslu je tělo „nepřítelem“ subjektu (Doel 1995). Toto tělo neobsahuje žádnou esenci a je vždy pouze praktikováno skrze aktualizující se praktiky. Je nekonečně proměnlivé v doslovném slova smyslu - tedy ne že by se metaforicky začínalo podobat něčemu jinému, co není ono samo. Skutečně a zcela doslovně se neustále „stává“ něčím jiným (např. stárne). Proto Doel s Clarkem (1999: 280-281) říkají: „Tělo není nijak dáno předem, ani se ničemu nepodobá. ,Tělo“ je spíše kompozicí a artikulací vztahů, jak sociálních, tak věcných.“

Následně se zaměříme na „stávání se“ struktury, tedy na „zestrukturnění“. Ve filozofii Deleuzeho a Guattariho (2010: 319-320) se toto „zestrukturněni““ odráží v rozmanitých kolektivních nevědomich. Kolektivní nevědomí (stejně jako subjekt) také není aktuální, nýbrž pouze virtuální. Zatímco proměnlivost těla umožňuje a stojí za virtualizací subjektu jako nekonečně probíhající „subjektifikací“, kolektivni nevědomí představuje to, co figuruje na straně virtuální struktury jako neustále „stávajícího se“ „zestrukturněni“. Kolektivní nevědomí se také vždy promítá do aktualizovaných praktik, aniž by jako takové aktuálně existovalo. A následně přes aktualizované praktiky může kolektivní nevědomí ovlivnit i průběh „subjektifikace“ - a tedy umožnit, že člověk a jeho tělo jsou praktikovány nějak a nikoli jinak - způsobit, že se u nich aktualizují tyto praktiky a nikoli jiné. Zatímco ze strany „subjektifikace“ přicházejí převážně potenciality rozvolňující stability, upevněné esence a struktury světa (které dávají prostor tělům, aby se stávala jinými těly), ze strany „zestrukturnění“ přicházejí zejména možnosti, které se snaží dosud upevněnou stabilitu a strukturaci udržet, př́ípadně ještě více stabilizovat. Tyto možnosti pritom vyvěrají z oněch kolektivních nevědomí.

Tento vztah však není deterministický, nebot’ je vždy obousměrný - virtuální „,subjektifikace“ zpětně přes aktuální praktiky tvaruje další stávání se kolektivního nevědomí. A tak kolektivní nevědomí nikdy nedosáhne plného „zestrukturněni“", plné uzavřené struktury, plné stabilizace a determinace praktik. Stále je uzavřeno v oblasti virtuálního - nikdy se nemůže plně zprítomnit, může se jen nadále virtuálně „stávat“. A to je právě důvod, proč poststrukturalismus (zejména ten v podání Deleuzeho a Guattariho) odmítá uchopit nevédomí podle větvících se a vzájemně se vylučujících konceptů: např́klad člověk bud' vidí zrakem, anebo nevidí; když nevidí, používá bud' jiný smysl nahrazující zrak, anebo používá jiný smysl způsobem nenahrazujícím zrak; a tak dále. V poststrukturalismu se kategorie neustále slučují a odlučují, prolínají a přeměňují, neustále se stávají jinak - tak jako každé tělo, i každé kolektivní nevédomí. $\mathrm{V}$ tomto textu chceme ukázat právě toto: jak jedno určité kolektivní nevědomí (které bude později nazváno vizuálním) promítá samo sebe do určitého praktikování tělesnosti, a tedy i do toho, jak se pro určité lidi (ty, jejichž těla nedisponují fyziologickým smyslem zraku) proměňuje virtuální „subjektifikace“. Na druhou stranu chceme zároveň ukázat, 
že virtuální „subjektifikace“ vrací úder a praktiky dále tvaruje po svém - způsobem, který se odlišuje od převládajícího praktikování těl, podle něhož bylo kolektivní nevědomí převážně „zestrukturněno“ (tedy těl disponujících fyziologickým smyslem zraku), a to nám samo o sobě může leccos o tomto kolektivním nevědomí a jeho funkci v současné společnosti prozradit.

\section{Vidění bez zraku}

Cílem této sekce tak bude narušit představu, že když je někdo nevidomý, nemůže vidět, respektive ukázat, jakými způsoby osoby nevidomé vidí. Slovníkem předchozí sekce se budeme věnovat tomu, skrze jaké virtuální možnosti osoby nevidomé praktikují své vidění. Postupně tak popíšeme specifika vidění nevidomých, které je odlišné od vidění vidomých, a na tomto rozdílu zviditelníme význam kolektivního nevědomí.

Člověk, který z jakéhokoli důvodu nevidí svět kolem sebe zrakem, neustále naráží na momenty, ve kterých je mu připomínáno, že nevidí. Setkává se s řadou možností, na kterých neumí participovat. Naši KP se setkávají s obtížemi využívat možnosti jako samostatně vstoupit do restaurace, usadit se ke stolu, přečíst si jídelní lístek, nalít si vodu do sklenice, úhledně krájet pokrm atp. Realizace velkého množství zcela běžných aktivit jako vědět, kde něco je, jaké to je, jak je to velké, kam to pokračuje, jak na to trefit, jak na to sáhnout, jak to uchopit, anebo naopak, jak se tomu vyhnout, je velmi náročné bez možnosti vidět. Nicméně to nutně neznamená, že by KP vidět nemohli. Lidé bez zraku také vcházejí do restaurací, usedají ke stolu, zjišt’ují, co mají na jídelníčku, objednávají si, nalévají si nápoje a byt' třeba neúhledně, ale krájejí své jídlo. Pouze to činí prostřednictvím aktualizace jiných možností, které jim jsou k dispozici. KP tak využívají asistence, používají hůl, chodí v doprovodu vodicího či asistenčního psa, opakovaně chodí na stejná místa, využívají vibrační indikátor výšky hladiny atp. Jinými slovy se v těchto kontextech aktualizují jiné možnosti pro vidění, které vycházejí z virtuálního potenciálu zažívání života, jež je jim pro vidění bez zraku $\mathrm{k}$ dispozici.

\footnotetext{
„No, tak já jsem to vždycky brala tak, že ta bílá hůl je taková jakoby právě prodloužená ruka, nebo takový jakože oko, který by ti mělo zprostředkovat prostě představu o tom, co v té cestě vlastně je.“ (Dana, 35, 13. 2. 2015, zvýraznění autorů)
}

Dana zde hovoří o tom, že ke svému vidění světa nevyužívá zrak, ale to neznamená, že svět nevidí, ona jej vidí, pouze jej vidí prostřednictvím aktualizace jiné virtuální možnosti než je využití zraku, v tomto konkrétním případě aktualizací virtuální možnosti hmatu. Hůl není úplně tak předmětem, je tak trochu tělem, je jakousi prodlouženou rukou, která hmatá, a tato prodloužená ruka, která hmatá, zase není úplně prodlouženou rukou, která hmatá, ale je jakýmsi náhradním okem, které umožňuje získat představu, co je před Danou na cestě, tedy určitým zpo̊sobem jí umožňuje vidět. Vidění se tak v tomto konkrétním případě Daniny výpovědi neaktualizuje skrze možnost využít zrak, ale skrze možnost využít hmat ruky, respektive dokonce skrze hmat hole v ruce. Vidění skrze hmat pak samozrejmě nemusí být realizováno pouze aktualizací virtuální možnosti dotýkat se věcí bílou holí, ale i našlapováním, ohmatáváním nohama, osaháváním rukama, ale v podstatě jakýmikoli částmi těl. Hmat 
tak představuje určitou možnost $\mathrm{v}$ rámci virtuálního potenciálu KP, který se aktualizuje ve snaze přizpůsobit se světu, ve kterém je třeba vidět, co je před nimi na cestě. Obdobně jako o hmatu pak lze uvažovat i o dalších smyslech. Druhou nejčastěji využívanou virtuální možností $\mathrm{k}$ aktualizaci vidění KP představuje sluch.

\begin{abstract}
„A je to hrozně zajímavý, protože ty zjistí̌s, že existuje, nebo nejspíš, když se tomu budeš věnovat, tak to nejspiš půjde zjistit, že existuje vlastně několik typů zvuků, který ta šalina vydává. Třeba existují zvuky, který vydává ten elektromotor, existují zvuky, který vydává jakoby ten svišstot toho vozidla, existují rázy, dunění, který ta šalina vydává, a ještě existuje chvění toho podloží, který ty koleje předávají do země. A všechno tohle to můžeš vnímat, jak se mění. Můžeš to docela dobře vnímat, dá se to a podle toho takhle jakoby toho dost zjistís." (Karel, 29, 24. 4. 2014, zvýraznění autorů)
\end{abstract}

Karel zde ukazuje, jaké všechny informace lze pomocí sluchu získat o tramvaji. Pomíjí zde ty rozměry, že tramvaj cinká, když se rozjíždí, že tramvaj umí mluvit a říkat o sobě, jak se jmenuje, na které zastávce se nachází, jaká zastávka bude následovat a k jakému cíli tramvaj směřuje, což jsou informace záměrně určené sluchu. Hovoří o dalších způsobech, kterými na něj tramvaj promlouvá, ze kterých je schopný číst, jak daleko od něj se tramvaj vyskytuje, jak rychle se pohybuje i třeba zda zrychluje či zpomaluje. V neposlední řadě z ní umí číst i informace o samotném prostoru, ve kterém se tramvaj pohybuje. Ví, že tam někde je ulice, kde jezdí tramvaj, kde je křižovatka či zastávka, umí určit, zda jde paralelně s ulicí, po které tramvaj jezdí, či kolmo k ní atp. Skrze využití virtuální možnosti slyšet tramvaj Karel získává množství informací o svém okolí, čímž se opět aktualizuje jeho možnost vidět. KP v tomto kontextu hovořili o sluchu velice často. Zajímavým tématem se pak stalo využití virtuální možnosti echolokace. Schopnost využít echolokace nicméně nedeklarovali všichni KP. Jinými slovy schopnost využít k vidění echolokaci je sice ve virtuálním potenciálu každého, kdo nemůže používat zrak a může používat sluch, nicméně ne u každého KP se aktualizuje do praktik. Jde o schopnost, která aby mohla být praktikována, musí se umět. Nicméně většina KP ji nějakým způsobem praktikuje. Někteří jen poslouchají zvuky, někteří jsou schopni se podle zdrojů těchto zvuků a směrů, odkud přichází, orientovat a někteří jsou schopni využívat i virtuální potenciál odrazu zvuku od klapání vlastních bot, od vlastního lusknutí či zatleskání. Takto praktikovaná echolokace nicméně neumožňuje „vidět“" cokoli. Je potřeba určitá schopnost věcí odrážet zvuk, která je v městském kontextu dána především materiálem, velikostí a výškou tohoto objektu. Např́íklad červenobílá páska kolem výkopu nenabízí virtuální potenciál využitelný pro „viděni““ pomocí echolokace, naopak např́ílad dům, auto, sloup veřejného osvětlení či strom jej nabízejí. Aktualizace virtuální echolokace do praktik tak není dána pouze individuálními schopnostmi KP, ale i materiální strukturou samotného prostředí.

Co je nicméně na výše zmíněném výroku Karla ještě zajímavé, je neoddělování jednotlivých smyslů od sebe. Když hovoří o zvuku, tak nehovoří pouze o sluchu, ale hovoří taktéž o rázech, dunění, chvění, které neslyší, ale vnímá. Obecně KP nehovoří o jednotlivých smyslech odděleně, ale tu kombinují sluch s hmatem, tu hmat s čichem, tu vnímají pohyb větru, tu namáhavost vlastního pohybu při stoupání do kopce či klesání z kopce, tu cítí slunce na jedné straně tváře, tu cítí vibraci, při jejichž popisech nepoužívají označení pro jednotlivé 
smysly jako je sluch, hmat, čich či chut', ale používají pro ně obecnější termíny jako cítit či vnímat. Pro své vidění bez zraku nicméně vưbec netematizují otázku chuti. Jinými slovy chut' v jejich virtuálním potenciálu nepředstavuje možnost, která by mohla být využita pro aktualizaci vidění bez zraku. Nejčastěji se tak v tomto kontextu prolínají pouze hmat, sluch a čich, které nicméně nejsou omezené pouze na dotek, zvuk či vůni, ale zahrnují nespočet vnímaných podnětů, které nelze jednoduše propojit pouze s jedním z těchto smyslů. Z výpovědí KP tak vyplývá, že k aktualizaci možnosti vidět nevyužívají zrak, ale využívají jakýsi „hmato-čicho-sluch“, tedy jakýsi multismyslový přístup. Pro účely tohoto příspěvku pro něj budeme dále používat obecnějšího termínu „vjem“, respektive „,nezrakový vjem“. Tento nezrakový vjem pro ně tedy představuje virtuální možnost, skrze kterou se aktualizuje jejich vidění světa. Jejich vidění se tak nepraktikuje zrakem, ale praktikuje se skrze jiné možnosti obsažené v jejich virtuálním potenciálu, tedy skrze využití tohoto nezrakového vjemu. Důvodem, proč je nicméně odlišení tohoto zrakového a nezrakového vidění důležité, je odlišnost vidění, která umožňují.

„No třeba vloni se mně stalo taky, překážka, tady bydlíme 30 let, 35 let a šel jsem od tramvaje, kolem budovy a vůbec jsem si neuvědomil, že tam je schodiště dolů, pod barák jako. A tam jako za těch 30 let jsem nikdy o to nezavadil jako jo a šel jsem okolo zdi a najednou jsem letěl po těch schodech dolů - 17 schodů [...] Nedávám pozor, nešahal jsem, že by tam ty schody mohly být, vůbec jsem s tím nepočítal.“ (Zdeněk, 68, 30. 4. 2014, zvýraznění autorů)

Zdeněk nám ve své výpovědi ukazuje, co znamená vidět prostřednictvím nezrakového vjemu. Zdeněk již 30 let bydlí na stejném místě, prochází kolem té stejné budovy, zná téměř každý záhyb na této cestě, cestu i přesto sleduje svým nezrakovým vjemem prostřednictvím aktualizace možnosti klepat holí, dotýkat se rukama, vnímat chodidly nohou, poslouchat své okolí atp. Svou cestu domů zná a i bez zraku ji vidí. Nicméně toto vidění má svá specifika. Zdeněk vidí jenom tady, jenom v jakémsi poměrně úzkém bezprostředním okolí svého těla, tady, kde jeho nezrakový vjem „dosáhne“ hmatem ruky, hmatem hole, čichem či kde odrazy zvuků, vzduchu či jiných vibrací se vracejí zpátky k němu. Je to vidění těsného okolí jakési bezprostřední obeznámenosti, kterou Zdeněk poměrně ostře vymezuje proti jakémusi širému tam. Tam, kam už nedohlédnu, tam, kam už nevidím, tam, kde to už neznám, tak tam je schodiště, a i když jsem kolem něj 30 let chodil, tak jsem o něj nikdy svým nezrakovým vjemem nezavadil, a tedy jsem jej ,přehlédl““ a ze schodiště spadl. Jiní KP podobně hovořili o tom, že málokdy mohou vidět, co je vedle chodníku, co je za obrubníkem, co je za plotem, za zábradlím, za zídkou, za výlohou, že je občas překvapí, že jdou kolem trávníku, kolem květin, kolem nějakého obchodu atp. Toto vidění toho, co je tam, tam dál, tam někde, je nicméně typické pro vidění realizované skrze aktualizaci možnosti vidět zrakem. Zrakové vidění nerozlišuje mezi tím tady a tam, plynule přechází po nejrůznějších blízkých i dalekých površích, čímž je spojuje v jeden hladký povrch. Ono těsně obeznámené tady je prostřednictvím zraku stejně viditelné jako ono širé tam. Vidění zrakem tedy nerozlišuje mezi tady i tam, mezi obeznámeností tady a širostí tam, oproti tomu pro vidění skrze nezrakový vjem jsou zcela něčím jiným. Zatímco ono bezprostředně obeznámené tady je prostřednictvím nezrakového vjemu viditelné, ona širost tam je příliš vzdálená, neurčitá, neuchopitelná a hlavně 
neviditelná. Nevidomost pak nutně neznamená absenci vidění, nevidomost znamená nemožnost vidět do dálky, nemožnost vidět tam někam na horizont, respektive nemožnost zahlédnout širost skrze aktualizaci potenciální možnosti vidět zrakem. Nevidomost je tak vytvářena předpokladem viditelnosti širosti, přičemž širost do virtuálního potenciálu přidává kolektivní vizuální nevědomí, které preferuje vidění jako aktualizaci vidění zrakem před aktualizací vidění nezrakovým vjemem.

\section{Vizuální nevědomí}

Předmětem této sekce bude blíže objasnit, co myslíme vizuálním nevědomím. Postupně se tedy budeme zabývat tím, odkud se vizuální nevědomí bere, z čeho čerpá své zdroje, co způsobuje a jak vstupuje do vidění nezrakovým vjemem. Nejprve tak ukážeme, že „viděni““ není jen předmětem fyziologie těla, ale je i způsobem samotného uchopování světa. Následně představíme, $\mathrm{v}$ čem je toto uchopování světa netělesné, respektive odtělesněné. A na závěr na př́íladu vývoje filmu popíšeme, jak toto odtělesněné uchopování světa umožňuje chápat prostor, který nemůže být př́mo vidět zrakem, jako kdyby byl vidět zrakem.

Praktiky vztahování se ke světu a praktikování každodenního žitého prostoru jsou pro lidi, kteří nevidí zrakem, strukturovány kolektivním vizuálním nevědomím, které je dominantně utvářeno praktikami těl, jež zrakem vidí. Ve smyslu aktualizujících se praktik a virtuálního „stávání se“ subjektu, který je vždy „tvořením-v-postupu“ a „stávání-se-jiným“, tu tedy máme „stávání-se-vidomým nevidomého ${ }^{10 ،}$. Kolektivní vizuální nevědomí tedy figuruje na straně virtuální struktury a společně s nevidomými lidmi jako virtuálními subjekty vytvář́ virtuální potenciál pro praktiky, které se mohou aktualizovat v kontextu těla, jež nevidí zrakem. Je ted' na místě ozřejmit si několik prvků z kolektivního vizuálního nevědomí, abychom mohli rríci, čím je specifické a čím se primárně promítá do praktikování vidění nezrakovým vjemem.

Zrak je sice tělesný fyziologický smysl, nicméně ani jako fyziologický smysl nefiguruje v sociálním vakuu. V sociálním životě je proto vždy vyjádřen a uchopován skrze diskurzivní i materiální praktiky viditelnosti a vizuality, nebot' to ostatně bylo právě moderní uchopení viditelnosti a vizuality pomocí zraku, které formovalo moderní vizuální nevédomí. Zde je důležitý onen odkaz na modernitu, která se otiskla do tohoto kolektivního nevědomí. Každá sociokulturní formace má totiž svou specifickou viditelnost, své specifické podmíněné vidění. „Viditelnosti tedy nejsou ani akty vidoucího subjektu, ani danostmi vizuálního smyslu“ (Deleuze 2003: 86). Viditelné není redukovatelné na vnímanou věc nebo smysl, protože „viditelné [...] jest jako vypovídatelné: je objektem nikoli fenomenologie, nýbrž epistemologie“ (Deleuze 2003: 74-88). Tímto je vyjádřeno nikoli to, že smyslové vnímání, jak s ním pracuje fenomenologie, zde ztrácí vypovídající smysl. Tímto je pouze řečeno, že se posouváme mimo dialektické vyřešení smyslového vnímání a diskurzivního poznání. Toto vyřrešení, tato syntéza se stále pohybuje na rovině, kde figuruje značná část fenomenologické tradice,

10 Uznáváme, že logičtější formulace by byla „stávání-se nevidomého vidomým“, nicméně jelikož je v deleuze-guattariánské tradici používáno ve tvaru „stávání-se-kým“, dodržujeme i my toto pořadí a používáme „stávání-se-vidomým nevidomého“. 
avšak poststrukturalismus již ne. V poststrukturalismu již není nějaká dialektická syntéza, nějaké vyřešení vztahu smyslového vnímání a diskurzivního poznání, nebot' zde již ani a priori neexistuje tento vztah. Viditelné je vždy již dopředu oboje (jak vnímání, tak i poznání), nic $\mathrm{v}$ sobě tedy nesyntetizuje, jen se pod vlivem různorodého virtuálního potenciálu nějak koprodukuje. Tedy nevlastnění zrakového smyslu není nikdy jen otázkou tělesnou (myšleno fenomenologickou), nýbrž je vždy a již předem i otázkou diskurzivní (tedy epistemologickou).

Praktiky, které se aktualizují mezi póly virtuálního subjektu jako nekonečně probíhající „subjektifikace“ a virtuální struktury jako nekonečně probíhajícího „zestrukturnění“, jsou obvykle více formovány moderním kolektivním vizuálním nevědomím (jež je odvislé od specifické zkušenosti vidění zrakem) než „subjektifikací“ lidí, kteří vidí nezrakovým vjemem (např. tvorba haptických map, které primárně vycházejí z mapy jako produktu vizuálního nevědomí a pouze ho (mapu jako vizuální reprezentaci) přizpůsobují pro nevizuální vnímání). Důvod je jednoduše ten, že v období dosavadního formování moderního vizuálního nevědomí byla zkušenost vidění zrakem brána jako ta normální zkušenost, zatímco odlišnost vidění nezrakovým vjemem nedostávala př́liš prostoru k projevení, a tak ani k ovlivnění dosavadního ,zestrukturnění“ vizuálniho nevědomí. Současný stav však není nějaký konečný bod vývoje. „Stávání se“ nadále probíhá a Biehl a Locke (2010: 322-323) tvrdí, že nekonečný virtuální potenciál kreativity a „stávání se“ má vždy jakýsi primát před stabilizací a upevňováním normativů. To, co se aktualizuje, tedy není nikdy otázkou jistoty, ale pouze virtuálního potenciálu. Potenciál, jenž vychází z kreativity virtuálního nevidomého subjektu, vždy nějak ovlivní praktiky, které by jinak byly formovány pouze kolektivním vizuálním nevědomím. V praktikách jsou tedy

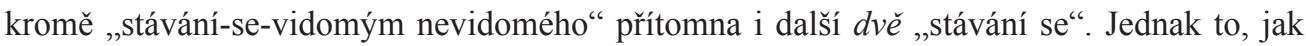
nevidomý, který se „stává“ vidomým, se vedle toho „stává“ ještě někým jiným, nebot' kolektivní vizuální nevědomí nemůže ovlivňovat jeho praktiky deterministicky, kdy k tomu v jeho př́ípadě přispívá zejména to, že nevidí zrakem. ${ }^{11}$ A jednak i to, jak se samotné moderní kolektivní vizuální nevědomí „stává“ ve své virtualitě dále něčím jiným, nebot' to, že reflektujeme tyto nové specifické praktiky, znamená, že se nám o jeho ,zestrukturnění“ cosi vyjevuje, a proto se otevírá potenciál vztahovat se k tomuto kolektivnímu nevědomí trochu jinak, trochu méně uznávat jeho strukturující sílu - což samo o sobě znamená, že se ,zestrukturnění“ může najednou trochu rozvolňovat. K tomu, co nám poskytuje toto umožněné rozvolnění, se vrátíme podrobněji v závěru. Ted' je čas si trochu více vysvětlit, co je vlastně na moderním vizuálním nevědomi to strukturující.

Základní znak moderního vizuálního nevědomi je, že je veskrze optické a zrakové, a vydává se proto za odtělesněné, přestože každý pohled, vidění a pozorování zůstávají neoddělitelně tělesné (Doel a Clarke 2002). Podle Robinse (1996: 29-33) je totiž rozparcelování a oddělení jednotlivých smyslových zkušeností samo o sobě moderní záležitostí. Gregory (1994: 63-69) odtělesněnou vizualizaci kritizuje a tvrdí, že je prostorovou „kolonizací žitého světa“. Podle Gregoryho (1994: 382-395) to vystihuje termín tzv. dekorporealizace prostoru, způsobené moderním vizuálním nevědomím, která abstraktní vizualizovaný prostor stále více odděluje od žitého hmotného a tělesného prostoru. Jedním z formativních činitelů moderního

11 Ani u lidí, kteří vidí zrakem, nejsou ovlivňovány jejich praktiky vizuálním nevědomím deterministicky, nicméně dá se tvrdit, že primárně z jiných důvodů než u lidí, kteří vidí nezrakovým vjemem. 
vizuálniho nevědomí bylo médium filmu, které od svého rozšíření na počátku 20. století zásadně změnilo prístup k časoprostoru jako takovému (Clarke a Doel 2005, 2007, 2016). Film umožnil nové uchopení časoprostoru tehdy, kdy se v něm zcela běžně začala používat technika montáže - tedy v době, kdy se pohyblivé obrazy začaly editovat, stř́íhat, kamera začala kreativně pracovat s jednotlivými záběry (přibližování a oddalování záběru, různorodě rozpohybovaná kamera i různá rychlost samotného záběru). Montáž tedy umožňuje pracovat různorodě se vztahem pohybu, prostoru a času (Deleuze 2000, 2006). Film představuje „vzájemné odkazování právě ,zabíraného“ ke kontextuálnímu ,mimo-záběr‘ a k tomu, co je očekávané, co teprve ,bude-v-záběru““ (Doel a Clarke 2007: 894). Pohyblivé obrazy filmu jako jeden z formativních prvků moderního vizuálního nevědomí přestaly být něčím, co odkazuje k určité realitě „tam někde“, a staly se něčím, co utváríí realitu „př́ímo tady“ - realitu, která má efekt a afekt (Doel a Clarke 2007). Problém je, že západní metafyzika má obrovský problém dostat se mimo uvažování o vzájemně se vylučující dichotomii realita - reprezentace (Doel 1999: 135-160), což znamená, že pohyblivé obrazy zůstávají vnímány jako reprezentace, a ne jako afektivní element přetvářející svět. Tato dichotomie se pak promítá do přesvědčení, že definitivně existuje určitá skutečnost „tam venku“, kterou nám (zrakem viditelné) pohyblivé obrazy zprostředkovávají.

$\mathrm{Z}$ toho plyne i relativně běžné přesvědčení, že $i$ když skutečnost nevidím, tak skutečnost je to, jako kdybych to viděl (zrakem). Podle Doela a Clarka (2007: 902-905) to s sebou přináší jakousi „ob-scénnost“ zrakového vidění v modernitě. Jinými slovy vizuální nevědomí je „ob-scénni'“, nebot' pohled a vidění jím formované nikdy nemůže být zcela dané, dokončené a úplné, a neustále se musí odkazovat $\mathrm{k}$ dalším záběrům, které jsou mimo tuto právě viděnou scénu. Podobně jako ve filmové montáži, cokoli, co je viděno (tj. je v záběru), je propojeno s kontextuálním „mimo-záběr“ (obraz, který lze odvodit ze současného záběru) a očekávaným „bude-v-záběru“ (obraz, který je očekáván, pokud se objeví na scéně nový prvek). To přivádí kohokoli, kdo vidí jinak než zrakem, do specifické situace: moderní vizuální nevědomí ovlivňuje praktiky, které se kolem něj dějí, tak, že je očekáváno, že jejich součástí bude vzdálený horizont a vizuální imaginace $\mathrm{i}$ toho, co je mimo záběr - na základě toho, co právě v záběru je. Navíc vizuální imaginace toho, co je mimo záběr, může být hodnocena podle toho, jak se vztahuje k realitě „tam venku“, která je v prostoru, jež sice v záběru právě nefiguruje, ale ten prostor je domýšlen, jako kdyby mohl být každou chvíli v záběru. To znamená, že kolektivní vizuální nevědomí směřuje člověka, který vidí nezrakovým vjemem, k praktikám určitého vypořádání se s diferencí (rýhou) mezi prostorem jako bezprostředností (který může přímo vidět svým zrakem) a prostorem jako širostí (který nemůže př́mo vidět svým zrakem) - tedy k praktikám, jako kdyby viděl zrakem. Tyto praktiky směřují k jakési nezrakové vizuální imaginaci širého prostoru a promítá se do nich „ob-scénnost“ moderního vizuálního nevědomí.

\section{Ob-scénnost bez zraku}

Jedna z vlastností vizuálního nevědomí je, že nerozlišuje mezi obeznámeností tady a širostí tam, ale veškerý prostor chápe pouze jako onu širost - vizuálně dostupnou širost. K této šrosti však nemají naši KP prŕstup. Předmětem této sekce tak je představit tři základní strategie, které používají $\mathrm{k}$ tomu, aby se s touto širostí prostoru vyrovnali i bez použití zraku. Jedná 
se o způsoby, které pracovně nazýváme i) přenesení svého těla do neaktuálního tady; ii) ohraničení prostoru; iii) pravoúhlost prostoru. Tímto výčtem tří strategií rozhodně nevyčerpáváme všechny možné strategie praktikování „ob-scénnosti“ nezrakovým vjemem. Nejde tedy o výčet konečný, ale spíše výběrový, který byl nejčastěji zmiňován ve výpovědích našich KP.

Je běžnou součástí našeho vizuální nevědomí, že si představujeme, že prostor vlastně nikde nekončí, že prostor stále někam pokračuje, že pokračuje i mimo naši aktuální scénu, za náš aktuální horizont, za roh, za budovu, za blok budov, přes několik dalších ulic, přes celou čtvrt', či dokonce přes celé město, a to nejen v rámci kontinuální cesty, ale i zcela střihově, do jiných míst a do jiných časů. Tam všude, i když aktuálně nejsme, kde se aktuálně nepohybujeme, si dokážeme prostor „před-stavit". Dokážeme plánovat naši budoucí cestu, dokážeme si „před-stavit“ trajektorii této cesty, dokážeme vidět naše budoucí kroky, vidět místa, ke kterým teprve míríme a která teprve navštívíme, a to nejen v posloupnosti našich cest, ale $\mathrm{i}$ ve střihově poskládané montáži libovolně vzdálených míst i časů. Jinými slovy dokážeme vystupovat ze své aktuální scény, z aktuálního záběru, který se nám naskýtá. Přičemž díky tomu vstupujeme jinam, někam tam, mimo, do jakéhosi neaktuálního, virtuálního místa, které náš zrak ani jakýkoliv jiný vjem není schopný aktuálně zaznamenat a mi do něj tedy vstupujeme pouze virtuálně, potenciálně, podobně jako to činíme s domýšlením toho, co je mimo aktuální záběr filmu. Tak jak nám pohled klouže a přeskakuje po površích aktuální scény, jsme schopní „vidět" i za tyto povrchy, jsme schopní ,vidět“" pokoje za oknem, ulice za rohem, budovy za domem, nikoli zrakem, ale díky zraku. Přestupujeme tak hranici aktuální scény. Vizuální nevědomí tak nejen že nerozlišuje mezi obeznámeností tady a širostí tam, ale veškerý prostor chápe jako onu širost tam, jako povrch, který stále někam pokračuje. Oproti tomu tuto možnost vystoupit prostřednictvím vidění zrakem ze svého obeznámeného tady do nějakého širého tam naši KP nemají ve svém virtuálním potenciálu a jsou tedy nuceni ob-scénnost aktualizovat prostřednictvím jiných praktik. První způsob, kterým je této nezrakové ob-scénnosti dosahováno, tak označujeme jako „přenesení svého těla do neaktuálního tady“.

Tazatel: Dalo by se zkusit si představit, tady ten obývák, kde jsme ted', abychom tady jako nebyli?

Petra: No, tak to fakt ne teda.

Tazatel: Nejde jo.

Petra: Ne.

Tazatel: Že si budu představovat ten prostor beze mě?

Petra: Ne, tak to si neumím jako. Jo tak prostě já když si to představím, tak prostě nevím, jak jinak si to mám představit, aniž bych jako stála jakoby $\mathbf{v}$ těch dveřích toho obýváku a takhle to popisovala. (Petra, 34, 9. 7. 2014, zvýraznění autorů)

Petra ve své výpovědi ukazuje, jak může vypadat absence možnosti praktikovat ob-scénnost prostřednictvím vidění zrakem. Virtuální potenciál v kontextu nemožnosti vidět zrakem tyto způsoby aktualizace nenabízí. Petra se tak uchyluje k jakémusi tělesnému představování prostoru. Ve výše uvedeném úryvku hovoří o představě bytu, ve kterém se právě nachází, nicméně podobným způsobem jsou KP schopni si představovat i místa, ve kterých se aktuálně fyzicky nenachází. Nicméně vždy je pro tento druh představy nutné představovat 
si zároveň $\mathrm{s}$ místem i sebe $\mathrm{v}$ něm. $\mathrm{V}$ jejich představě tak nelze oddělit představovaný prostor od toho, kdo si jej představuje, pozorovaný prostor od pozorujícího, viděný prostor od vidoucího. Nelze abstrahovat od pozice, postoje, pohledu, respektive perspektivy těla, které vidí fyzicky neaktuální prostor. KP si tak nepředstavují prostor z nějakého vzdáleného, nekonkrétního, božího pohledu, ale z tělem známé, zcela konkrétní a používané perspektivy. Jejich tělo je vždy at' již staticky či v pohybu přítomno $v$ jejich představě a tak i když se jedná o představy fyzicky neaktuálních míst, nejedná se o ob-scénní představy virtuálních míst. Ob-scénnost tak $\mathrm{v}$ tomto kontextu není praktikována odtělesněným viděním vzdálených tam, ale pouze skrze přenesení své tělesné perspektivy mimo fyzicky aktuální tady, do fyzicky neaktuálního tady. Tímto způsobem praktikování ob-scénnosti se KP nicméně nedostávají $\mathrm{k}$ širosti prostoru, $\mathrm{k}$ onomu širému, tam, ale vždy jen $\mathrm{k}$ dalším obeznámeným tady. Tyto praktiky ob-scénnosti tak navrací virtuálnímu vizuálnímu nevědomí jeho tělesnost, respektive ukazují, že kolektivní vizuální nevědomí není tak dekorporealizované, jak by se mohlo na první pohled zdát. Druhý způsob praktikování ob-scénností bez zraku nazýváme: „ohraničení prostoru“.

„Já si myslím, teda můj osobní pocit je, že to za prvé může souviset s tím mým takovým divným pocitem, z toho, jak mi všechno přijde hrozně veliký, tak já se tam prostě cítím často jakoby ztraceně. Kdež to, když jsi v nějakým interiéru, byt' je to prostě, nemusí to být jedna místnost, může to být prostě budova, tak pro mě je to pořád jakoby něco ohraničeného. Pro mě pořád ten prostor má nějaký hranice, nějaký omezení. Což venkovní nemá, to je prostě. A to je pro mě někdy tak velký sousto, že si vždycky ř́íkám: No, ty jo, jako tak tady jsem se schopná zamotat na 10 metrech, jo.“ (Dana, 35, 13. 2. 2015, zvýraznění autorů)

Dana zde staví do jakéhosi pomyslného protikladu širost venkovního prostoru a širost vnitřních prostorů. Zatímco širost venkovního prostoru je pro ni něčím téměř děsivým, se širostí interiérů již dokáže nějak pracovat. Přičemž je v tomto rozlišení klíčová nějaká hranice, nějaké ohraničení, prostorové omezení. $\mathrm{V}$ př́ípadě vnitřních prostorů jsou těmito hranicemi zdi, podlahy a stropy jednotlivých místností. $\mathrm{V}$ prípadě venkovních prostor tyto hranice mohou a nemusí existovat, jinými slovy virtuální potenciál vůbec nemusí umožňovat aktualizaci omezení širosti prostoru prostřednictvím hranice. V př́padě úzkých uliček, podloubí, cesty podél domu lze využít alespoň dílčí možnosti ohraničení širosti prostoru, nicméně KP často vypovídají o nemožnosti takovéto aktualizace, a to když prostor žádné takové materiální hranice nenabízí. Často jsou tak KP nuceni pohybovat se volným, rozlehlým a ničím neohraničeným (často dokonce ničím nestrukturovaným) prostorem, jako jsou široké ulice, křižovatky, přechody, náměstí, parky, parkoviště atp. V takových širých prostorech, ve kterých neexistují možnosti, které by umožnily rozčlenit jejich širost na menší širost, které by je umožnily zmenšit, ohraničit, uzavřít, se KP cítí ztraceně. Ona širost je vnímána jako rozlehlost a prostory jako veliké, prázdné, nekonečné, ve kterých je velmi snadné ztratit orientaci a zamotat se. Vyhýbání se neohraničeným prostorům, jejich neustálé ohraničování a preferování těch již ohraničených tak představuje další způsob praktikování „ob-scénnosti“. KP vystupují z jejich bezprostředně obeznámeného tady, vystupují ze svého aktuálního záběru či scény a vstupují do „ob-scénního“ prostoru mimo tuto scénu bezprostřední 
obeznámenosti, ale pouze za předpokladu, pokud virtuální potenciál obsahuje možnost využít jiný rámec (ohraničit onu širost mimo scénu), za který je nejčastěji využívána materialita místností či budov. KP tak praktikují „ob-scénnost“ svého vidění nezrakovým vjemem pouze v prípadech, kdy vědí, že se nemohou v oné ohraničené širosti „utopit“, ale vždy mají možnost v ní „doplavat ke břehu“. Třetí způsob dosahování „ob-scénnosti“" pomocí nezrakového vjemu označujeme jako „pravoúhlost prostoru“.

\begin{abstract}
„Když já prostě vím, že když budu od koleje doprava a hned zas doprava, tak budu na Šumavský a ta je přesně v pravém úhlu vi̊či Kounicový, což se pozná např́ílad podle toho, že mi za zády budou jezdit auta a budou za zády jezdit prostě zleva doprava, tak vím, že jdu po pravoúhlý ulici, respektive kolmý k té, po které jsem šel předtím. A když se nic nezmění a dojdu ke kolejím, tak v tu chvíli, kdy jsem narazil na ty koleje, tak se mi spojí ta rovnoběžnost.“ (Michal, 29, 28. 2. 2015, zvýraznění autorů)
\end{abstract}

Třetí a v tomto príspěvku poslední ukázkou praktikování „ob-scénnosti“ lidí bez zraku je využití úhlové strukturace prostoru. Úhel představuje geometrickou veličinu, která je odvozena od a připravena pro vidění zrakem. KP rozumí úhlům jako jakési míre, o kterou musí pootočit své tělo, pokud se chtějí pohybovat $\mathrm{v}$ prostoru, který svírá nějaký úhel. Současně hovoří o tom, že je pro ně velmi náročné odhadovat tuto míru, o kterou mají pootočit své tělo, tedy odhadovat směr pohybu podle úhlů. Když KP už úhly využívají, nejčastěji hovoří o úhlech pravých a jejich násobcích (o kolmosti, o rovnoběžnosti). Michal ve svém úryvku ukazuje, že tělo lze do jisté míry chápat jako čtyřstěnné, jako to, co má přední část, zadní část, pravou stranu a levou stranu. Určitý prostor tak je před ním, určitý za jeho zády, určitý napravo od něj a určitý nalevo od něj. Celý prostor kolem těla lze rozdělit do jakýchsi čtyř kvadrantů, odvozených právě od pozice těla. Otočení o 90 stupňů jedním směrem (např́klad doprava) představuje změnu orientace o jeden kvadrant. To, co bylo před Michalem, se přesune na jeho (levou) stranu a to, co bylo na (pravé) straně, se přesune před něho. Změna směru o jiné úhly než je 90 stupňů, je podle slov KP pro ně náročná. Nicméně sama možnost aktualizovat při svém pohybu virtuální potenciál využití pravého úhlu umožňuje Michalovi praktikování „ob-scénnosti“ v podobě dosahování kolmých či rovnoběžných míst, které se nacházejí mimo jeho aktuální tady bezprostřední obeznámenosti. Ve chvíli, kdy Michal hovoří o tom, že se mu to spojí, že se mu spojí ta rovnoběžnost, tak hovoří o tom, že se mu spojuje místo jeho aktuálního bezprostředního tady s nějakým tam, ke kterému ono tady odkazuje skrze aktualizaci virtuální možnosti využití pravého úhlu. Užíváním pravého úhlu tak KP vystupují ze své aktuální scény, vstupují za scénu a opět tak praktikují „ob-scénnost“.

\title{
Závěr
}

Příspěvek se věnoval prostorovému znevýhodnění, konkrétně smyslovému prostorovému znevýhodnění - nevidomosti. Nicméně př́spěvek toto znevýhodnění nechápe jako předmět svého zájmu, ale daleko spíše jako perspektivu, skrze kterou se snaží zviditelnit jakousi domněle odtělesněnou perspektivu, ze které se běžně díváme na prostory nejen našich měst. Tato perspektiva se otiskuje i do teoretických diskusí o městském prostoru a my ji v rámci 
tohoto př́spěvku nazýváme vizuální nevědomí. Použitý empirický materiál, tedy zkušenost $16 \mathrm{KP}$, které podle vlastních slov nevidí, nám umožnil zviditelnit něco, co je pro ty, kdo vidí zrakem, obtížně rozpoznatelné. Zkušenost nevidomých KP umožňuje nahlédnout, jak vizuálni nevědomí upřednostňuje vidění zrakem před jakýmkoli jiným viděním. Skutečnost, že někdo nemá zrak, ještě neznamená, že nevidí. Pouze vidí jiným způsobem. V rámci vizuálního nevědomí je však každý vjem jednoznačně spojen pouze s jedním smyslem, a vidění je tak jednoznačně spojeno pouze se zrakem. Praktikování vidění skrze jiné možnosti, než je využití zraku, je pak v rámci vizuálního nevědomi obtižné už jen nazvat viděním. Toto nezrakové vidění, vidění realizované prostřednictvím jakéhosi „hmato-čicho-sluchu“, které v př́spěvku nazýváme nezrakovým vjemem, je však odlišné od vidění zrakem a opět nám umožňuje říci něco o vizuálním nevědomí.

Totiž tím, že ono vidění prostřednictvím nezrakového vjemu rozlišuje mezi bezprostř̌edním tady a širým tam, nám ukazuje, že vidění zrakem toto tady a tam naopak nerozlišuje, a volně tak klouže po površích prostoru jako po obraze. Vizuální nevědomí tak chápe prostor jako širost, jako mozaiku nejrůznějších tam. Vizuálni nevědomí je slepé k prostoru viděnému jinak než zrakem, $\mathrm{k}$ bezprostřednímu prostoru obeznámeného tady. Nevidíme vidícího, nevidíme pozorovatele, nevidíme toho, kdo se dívá, z jaké perspektivy se dívá, jakým způsobem se dívá, z jaké konkrétní pozice těla se dívá ani čím se dívá, vidíme jen prostor, který vidí. Oddělujeme tak pozorovatele od pozorovaného. KP nám naopak ukazují, že toto neumí, že neumí oddělit prostor, který vidí, od své situovanosti v něm. Přitom nevidí jenom jinak, ale vidí i něco jiného, vidí pouze bezprostřední obeznámenost, která je ale naopak neviditelná pro vizuálni nevědomí. KP nevidí díru označenou červenobílou páskou, nevidí oranžovou poštovní schránku trčící ze zdi, nevidí otevřený kufr auta, závoru, plot, zábradlí atp. Lidé vidící zrakem zas naopak nevidí prostor mezi červenobílou páskou a dírou $\mathrm{v}$ zemi, hloubku oranžové poštovní schránky, chybějící zarážky pro hůl u plotů a zábradlí. KP nevidí prostor širosti, ale vidí sami sebe, lidé se zrakem vidí prostor, ale nevidí jeho pozorovatele, jeho perspektivu, jeho tělesnou pozicionalitu, a dokonce nevidí ani svou tělesnou pozicionalitu. Jinými slovy lidé vidoucí zrakem nevidí, že vidí jenom zrakem. Urbánní prostor, který je primárně aktualizován lidmi vidoucími zrakem, je především prostorem širosti. Haussmanizace Pařǐže, modernistická přestavba měst, prorážení ulic, rozšiřování bulvárů, budování otevřených širokých prostorů, využívání průhledných či lesklých materiálů, plánování průhledů, pohledových dominant a panoramat, výškové regulativy staveb atp. jsou pouze př́klady, ve kterých lze identifikovat dominanci principu širosti před principem bezprostřednosti při budování urbánního prostoru. Tato dominance principu širosti je pokládána za něco zcela samozřejmého, přičemž není reflektováno, že se jedná pouze o jednu tělesnou pozicionalitu.

Zkušenost KP nám ukazuje, že vizuální nevědomi při nazírání na urbánní prostor abstrahuje od tělesné pozicionality. Na druhou stranu nám ta samá zkušenost KP ukazuje, že vizuální nevědomí není zcela odtělesněné. Strategie praktikování „ob-scénnosti“ bez využití zraku nabízí několik př́íkladů tělesnosti vizuálního nevědomí. V prŕípadech, když se KP přesouvají do jiných fyzicky neaktuálních tady, když při rámování scény vystupují z hranic bezprostřední obeznámenosti aktuálního tady a namísto nich využívají obvodových zdí budov a místností, nebo když využívají pravých úhlů k propojení vzdálených míst mezi sebou, tehdy vystupují ze scény, kterou vidí svým nezrakovým vjemem, a praktikují „ob-scénnost“. Při svém 
„stáváním-se-vidomým“ KP dochází k aktualizování praktik, které proměňují virtuální potenciál vizuálního nevědomí, který umožňuje vidět širost i lidem bez zraku. Vidění širosti nezrakovým vjemem nám pak umožňuje zviditelnit onu rýhu mezi bezprostředním tady a širým tam, respektive nám umožňuje vidět jinak neviditelný prostor bezprostředně obeznámeného tady, které je uzavřené do velmi malého množství odkazování někam jinam, někam mimo ono dobře ohraničené a především vlastnímu tělu obeznámené tady. Zbaveni nepřeberného množství zrakového odkazování mimo scénu můžeme najednou lépe uvidět naši tělesnou pozicionalitu, náš způsob vidění prostoru zrakem, a dokonce i pozici, ze které se zrakem díváme. Neočekáváme, že toto „vidění“ světa z tělesné pozice vidoucího zrakem může samo o sobě nějak radikálně proměnit pohled na (městský) prostor, očekáváme však, že může učinit viditelným celou řadu prostorových, respektive urbánních témat, která by jinak zůstala „neviditelná“. Podobně jako se geografii znevýhodnění (disability geography) podařilo opustit čistě sociální pojetí prostorového znevýhodnění a posunout se k hledání diskurzivně-materiálního pojetí znevýhodnění na úrovni výzkumných témat, je o tomto posunu možné uvažovat i na úrovni perspektiv. Tedy posunout se od reflexe sociální pozicionality výzkumníka k tělesné pozicionalitě výzkumníka, a díky ní se tak podívat na město nejen bez zraku.

\section{Literatura}

ABBERLEY, Paul. 1987. „The Concept Of Oppression and The Development of a Social Theory Of Disability.“ Disability, Handicap \& Society 2(1): 5-19.

ANDREWS, Sona Karentz. 1983. „Spatial Cognition Through Tactual Maps.“ Pp. 30-40 in Joseph WIEDEL (ed.). Proceedings of the 1st International Symposium on Maps and Graphics for the Visually Handicapped. Washington: Association of American Geographers.

BIEHL, Joao a Peter LOCKE. 2010. „Deleuze and the Anthropology of Becoming.“ Current Anthropo$\log y$ 51: 317-351.

BUTLER, Ruth. 1995. „What You See is What You Get: Urban Information Systems for Visually Impaired People." Pp. 5-7 in 10th Urban Change and Conflict Conference. London: Royal Holloway, University of London.

BUTLER, Ruth a Sophia BOWLBY. 1997. „Bodies and Spaces: An Exploration of Disabled People’s Experiences of Public Space.“ Environment and Planning D: Society and Space 15(4): 411-433.

BUTLER, Ruth a Hester PARR. 1999. Mind and Body Spaces: Geographies of Illness, Impairment and Disability. London: Routledge.

CHOUINARD, Vera. 1999. „Life at the Margins: Disabled Women's Explorations of Ableist Spaces.“ Pp. 142-156 in Elizabeth KENWORTHY TEATHER (ed.). Embodied Geographies: Spaces, Bodies and Rites of Passage. London: Routledge.

CHOUINARD, Vera a Ali GRANT. 1995. „On Being Not Even Anywhere Near ,The Project‘: Ways of Putting Ourselves in The Picture.“ Antipode 27(2): 137-166.

CLARKE, David B. a Marcus A. DOEL. 2005. „Engineering Space and Time: Moving Pictures and Motionless Trips.“ Journal of Historical Geography 31: 41-60.

CLARKE, David B. a Marcus A. DOEL. 2007. „Shooting Space, Tracking Time: The City from Animated Photography to Vernacular Relativity.“ Cultural Geographies 14: 589-609.

CLARKE, David B. a Marcus A. DOEL. 2016. „Cinematicity: City and Cinema after Deleuze.“ Journal of Urban Cultural Studies 3: 3-11. 
CRESSWELL, Tim. 1996. In Place/Out of Place: Geography, Ideology and Transgression. London: UCL Press.

DEAR, Michael, Sharon Lord GABER, Lois TAKAHASHI a Robert WILTON. 1997. „Seeing People Differently: The Sociospatial Construction of Disability." Environment and Planning D: Society and Space 15(4): 455-480.

DELEUZE, Gilles. 2000. Film 1: Obraz-pohyb. Praha: Národní filmový archiv.

DELEUZE, Gilles. 2003. Foucault. Praha: Hermann \& synové.

DELEUZE, Gilles. 2006. Film 2: Obraz-čas. Praha: Národní filmový archiv.

DELEUZE, Gilles. 2014. Záhyb: Liebniz a baroko. Praha: Hermann \& synové.

DELEUZE, Gilles. 2016a. Nietzsche a filozofie. Praha: Hermann \& synové.

DELEUZE, Gilles. 2016b. Spinoza: Praktická filozofie. Praha: Oikoymenh.

DELEUZE, Gilles a Félix GUATTARI. 2010. Tisic plošin. Praha: Hermann \& synové.

DOEL, Marcus A. 1995 „Bodies without Organs: Schizoanalysis and Deconstruction.“ Pp. 208-221 in Steve PILE a Nigel THRIFT (eds.). Mapping the Subject. London: Routledge.

DOEL, Marcus A. 1996. „A Hundred Thousand Lines of Flight: A Machinic Introduction to the Nomad Thought and Scrumpled Geography of Gilles Deleuze and Félix Guattari.“ Environment and Planning D: Society and Space 14: 421-439.

DOEL, Marcus A. 1999. Poststructuralist Geographies: The Diabolical Art of Spatial Science. Edinburgh: Edinburgh University Press.

DOEL, Marcus A. 2000. „Un-glunking Geography: Spatial Science after Dr Seuss and Gilles Deleuze.“ Pp. 117-135 in Mike CRANG a Nigel THRIFT (eds.). Thinking Space. London: Routledge.

DOEL, Marcus A. a David B. CLARKE. 1999. „Virtual Worlds: Simulation, Suppletion, S(ed)uction and Simulacra." Pp. 261-284 in Mike CRANG, Phil CRANG a Jon MAY (eds.). Virtual Geographies. Abingdon: Routledge.

DOEL, Marcus A. a David B. CLARKE. 2002. „Lacan: The Movie.“ Pp. 69-93 in Tim CRESSWELL a Deborah DIXON (eds.). Engaging Film: Geographies of Mobility and Identity. Lanham: Rowman \& Littlefield.

DOEL, Marcus A. a David B. CLARKE. 2007. „Afterimages.“ Environment and Planning D: Society and Space 25: 890-910.

GLEESON, Brendan. 1996. „A Geography for Disabled People?“ Transactions of the Institute of British Geographers 21(2): 387-396.

GLEESON, Brendan. 1999. Geographies of Disability. London: Routledge.

GLEESON, Brendan. 2001. „Disability and the Open City.“ Urban Studies 38(2): 251-265.

GOLLEDGE, Reginald G. 1993. „Geography and the Disabled: A Survey with Special Reference to Vision Impaired and Blind Populations." Transactions of the Institute of British Geographers 18(1): 63-85.

GOODLEY, Dan, Bill HUGHES a Lennard DAVIS. 2012. Disability and Social Theory: New Developments and Directions. Basingstoke: Palgrave Macmillan.

GREGORY, Derek. 1994. Geographical Imaginations. Cambridge: Blackwell.

HALL, Edward. 2000. ,,,Blood, Brain and Bones“: Taking the Body Seriously in the Geography of Health and Impairment.“ Area 32(1): 21-29.

HALL, Edward a Robert WILTON. 2017. „Towards a Relational Geography of Disability.“ Progress in Human Geography 41(6): 727-744.

HANSEN, Nancy a Chris PHILO. 2007. „The Normality of Doing Things Differently: Bodies, Spaces and Disability Geography." Tijdschrift voor economische en sociale geografie 98(4): 493-506.

IMRIE, Rob. 1996. „Ableist Geographies, Disablist Spaces: Towards a Reconstruction of Golledge“s ,Geography and the Disabled'“" Transactions of the Institute of British Geographers 21(2): 397-403.

KITCHIN, Rob. 1998. „, Out of Place“, ,Knowing One‘s Place‘: Space, Power and the Exclusion of Disabled People.“ Disability \& Society 13(3): 343-356. 
KITCHIN, Rob. 2008. „Reginald Golledge.“ Pp. 136-142 in Phill HUBBARD, Rob KITCHIN a Gill VALENTINE (eds.). Key Thinkers on Space and Place. London: Sage.

LEY, David. 2000. „Behavioural Geography.“ Pp. 42-45 in Ronald John JOHNSTON, Derek GREGORY, Geraldine PRATT a Michael WATTS (eds.). The Dictionary of Human Geography. Malden: Blackwell Publishers.

MASSEY, Doreen. 2005. For Space. London: Sage.

MAY, Todd. 1994. The Political Philosophy of Poststructuralist Anarchism. University Park: The Pennsylvania State University Press.

MURDOCH, Jonathan. 2006. Post-Structuralist Geography: A Guide to Relational Space. London: Sage.

NEWMAN, Saul. 2005. Power and Politics in Poststructuralist Thought. Abingdon: Routledge.

OLIVER, Mike. 1990. The Politics of Disablement. London: Macmillan.

OLIVER, Mike. 1991. „Disability and Participation in the Labour Market.“ Pp. 132-146 in Phillip BROWN a Richard SCASE (eds.). Poor Work: Disadvantage and the Division of Labour. London: Open University Press.

OLIVER, Mike. 1993. „Disability and Dependency: A Creation of Industrial Societies?“ Pp. 49-60 in John SWAIN, Sally FRENCH, Colin BARNES a Carol THOMAS (eds.). Disabling BarriersEnabling Environments. London: Sage.

OLIVER, Mike. 1996. Understanding Disability: From Theory to Practice. New York: St Martin's Press.

OSMAN, Robert a Lucie POSPÍŠILOVÁ. 2016. „Zkušenost bez zraku: př́ležitost pro reflexi prostorového normativu.“ Gender, rovné př́ležitosti, výzkum 17(1): 63-76.

OSMAN, Robert. 2019. „Jet pěšky / Geografie ,vozíčkářů a vozíčkářek“ “ Pp. 29-67 in Robert OSMAN a Lucie POSPÍŠILOVÁ (eds.). Geografie „okrajem“: každodenní časoprostorové zkušenosti. Praha: Karolinum.

PARK, Deborah C., John P. RADFORD a Michael H. VICKERS. 1998. „Disability Studies in Human Geography." Progress in Human Geography 22(2): 208-233.

PHILLIPS, Martin. 2005. Contested Worlds : An Introduction to Human Geography. Aldershot: Ashgate. PORKERTOVÁ, Hana. 2017. Nevidomá zkušenost: disabilita jako asambláž a vztah mezi tělem, diskurzem a zkušeností. Brno: Masarykova Univerzita. (Disertační práce)

ROBINS, Kevin. 1996. Into the Image: Culture and Politics in the Field of Vision. London: Routledge.

SHAKESPEARE, Tom. 1993. „Re-Presenting Disabled People.“ Disability, Handicap \& Society 8(1): 95-101.

SHAKESPEARE, Tom. 1995. „Re-Defining the Disability Problem.“ Critical Public Health 6(2): 4-9.

SHAKESPEARE, Tom. 2006. Disability Rights and Wrongs. London: Routledge.

SHAKESPEARE, Tom. 2014. Disability Rights and Wrongs Revisited. New York: Routledge.

WOLCH, Jennifer a Michael DEAR. 1989. The Power of Geography: How Territory Shapes Social Life. Boston: Unwin Hyman.

WOLPERT, Julian. 1964. „The Decision Process in Spatial Context.“ Annals of the Association of American Geographers 54(4): 537-558.

\section{Autoři}

Robert Osman je sociální geograf působící jako odborný asistent na Geografickém ústavu Masarykovy univerzity a současně jako odborný pracovník v Oddělení environmentální geografie na Ústavu geoniky AV ČR, v.v.i. Mezi jeho hlavní výzkumná témata patří geografie času, rytmicita místa, časoprostorová zkušenost, lidská teritorialita a geografie znevýhodnění. Využívá především kvalitativních výzkumných metod, o jejichž širší etablování 
v rámci tuzemské geografie se snaží, například zaváděním nových metodických kurzů v rámci Geografického ústavu MU. Editoval knihy Prostor(y) geografie (2014, Karolinum) a Geografie „okrajem “ (2019, Karolinum).

Kontakt: Př́rodovědecká fakulta Masarykovy univerzity, Geografický ústav, Brno; osman@ mail.muni.cz; Ústav geoniky AV ČR, v. v. i., Brno; robert.osman@ugn.cas.cz; ORCID 0000-0002-1066-7664.

Pavel Doboš je kulturní geograf působící jako odborný pracovník na Geografickém ústavu Masarykovy univerzity. Zajímá se především o kritické a poststrukturalistické př́stupy v kulturní geografii a sociální antropologii. Jeho interdisciplinární výzkumný zájem se týká témat z oblasti postkoloniálních studii a afrických studií, z oblasti mediálních studií a geografie komunikace, z oblasti geografie znevýhodnění a z oblasti vizuálních studií.

Kontakt: Př́rodovědecká fakulta Masarykovy univerzity, Geografický ústav, Brno; pdobos@ mail.muni.cz 